\title{
Exploring Village Funds Management on The Perspective Capacity Village Apparatus's of Bengkulu Province in 2018- 2019
}

\author{
Titi Darmi ${ }^{1}$, Iqbal Miftakhul Mujtahid ${ }^{2}$ \\ ${ }^{1}$ Public Administration Program, Universitas Muhammadiyah Bengkulu, Indonesia \\ \& Kampus 4 UMB, Jalan H. Adam Malik Kota Bengkulu. \\ 2Public Administration Program, Universitas Terbuka, Indonesia \\ Corresponding Author: iqbal@ecampus.ut.ac.id \\ doi) https://doi.org/10.18196/jgpp.v8i3.11745 \\ Article Info
}

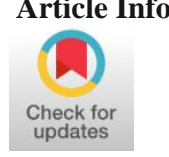

Article History;

Received:

2021-05-06

Revised:

2021-07-12

Accepted:

2021-09-04

\begin{abstract}
This study aimed to determine the extent to which the village apparatus's capacity can manage village funds. This study used qualitative and quantitative approaches, namely frequency percentage statistics. Results of distribution utilized the total score of the answers. Data sources included primary and secondary data. Data sources included primary and secondary data. The object of research is 30 (thirty) villages, 2 respondents from each village are taken. Findings demonstrate that the village apparatus's capacity in managing village funds is generally assessed from their basic Capability, management capability, and technical Capability, which fall into the 'fair' category. It indicates that the village apparatus needs to increase its capacity so that village funds can be managed optimally. The solutions include increasing the HR-village apparatus's capacity through computer training, technical guidance, seminars, and socialization of related regulations. Besides, facilitation and mentoring are the best ways that the village apparatus needs to increase their capacity, considering that stakeholders are demanding a change in the paradigm of implementation in village governance and the era of disruption to balance and harmonize with current and future conditions.
\end{abstract}

Keyword: Village autonomy; capacity building; village funds; HR-village apparatus.

\section{INTRODUCTION}

Village Fund Policy has potential in all respects, significantly accelerating village development, economic growth, and increasing rural communities' capacity. It is by the mandate of the Village Law and regulations governing the use of village funds. However, this potential cannot be managed optimally if the village does not have Human Resources (HR), namely village apparatus who are competitive, professional, and have integrity.

Furthermore, the village fund is part of the mandate of the Village Law. This Law's application is reflected in the Village Fund (APBDes) budget in the State Budget (APBN). It is an embodiment of achieving President Jokowi's vision and mission of Nawacita (a nine-point development program). It is stated that Indonesia's development starts from the periphery, meaning that rural development is a priority. To ensure that this ideal is by the Law's expectations, the management of funds must be right on target. Thus, it needs professional human resources.

Corruption Eradication Commission (KPK) has identified four problems in Village Fund management, including regulation, institution/management, supervision, and the quality and integrity of human resources as the manager of village funds. One of the issues that need to be 
followed up is Human Resources (Village Apparatus) as the actors in managing village funds (RI, 2015).

According to the Ministry of Finance (2016), the evaluation of the Directorate General of Fiscal Balance (DJPK) of the Ministry of Finance of the Republic of Indonesia in 2015 found that Village Funds were mostly used for physical development, village infrastructure by $83.9 \%$. The remaining $16.1 \%$ of the Village Funds were used for community economic empowerment, government activities, social activities, and others. The results of the DJPK evaluation on the Management of the Village Funds are shown in table 1 below:

Table 1. The Use of Village Funds

\begin{tabular}{clc}
\hline No & \multicolumn{1}{c}{ The Use of Village Funds } & $\begin{array}{c}\text { Percentage of the Use of Village } \\
\text { Funds }\end{array}$ \\
\hline 1 & Infrastructure development activities (physical) & $83.9 \%$ \\
\hline 2 & Village community economic empowerment activities & $6.5 \%$ \\
\hline 3 & $\begin{array}{l}\text { Governance activities and government administration } \\
\text { financing }\end{array}$ & $5.7 \%$ \\
\hline 4 & Community social activities & $3.8 \%$ \\
\hline 5 & Others & $0.1 \%$ \\
\hline
\end{tabular}

Source: DJPK, Ministry of Finance, 2018.

The table above demonstrates that Village Funds is dominated by infrastructure development activities, namely physical development by $83.9 \%$. Additionally, the allocation of village funds in governance activities and village administration financing is only $5.7 \%$. It means that it is essential to carry out a thorough analysis to prepare an activity program plan to optimize village funds. The program plan arrangement requires people who have qualified capacity so that the village has desired outcomes in the future.

Based on research in 2018 related to strengthening village funds' management capacity, it was found that village funds could not be managed optimally due to the low capacity of village government institutions. One of the institutional dimensions is Human Resources (Village Apparatus), which is not yet qualified. The results of this study recommend that it is necessary to follow up on the Village Fund and emphasize that it is urgent to increase the village apparatus's capacity at the research site. Based on education, training, workshops that have been carried out, and performance indicators of village government institutions, $80 \%$ of the 30 villages on the research site have inadequate Village Apparatus (Mujtahid \& Darmi, 2019).

The following indicators can see the weak capacity of village apparatus in managing village funds: 1) The formulation of the Village Budget (APBDes) and development programs sourced from the Village Fund have not been by the needs of the community; 2) HR-Village Apparatus has not been able to put forward the priority programs contained in the Village Budget so that the Village Fund does not yet have an outcome for the village and community; 3) reports of Village Fund activities still use a third party which has implications for budget waste; 4) There are reports from the village community that there are procedural irregularities in the Management of the Village Fund so that it has the potential to harm the community (State) (Darmi \& Mujtahid, 2019). To overcome this, the Village Apparatus should have at least 3 capacities/capabilities in managing their village, namely: 1) Individual capacity - village officials have knowledge, experience, culture of behaviour (care, share and respect) and motivation; 2) Organizational Capacity - the apparatus has basic capabilities, management capabilities and technical capabilities-; 3) System Capacity village officials understand all related regulations regarding the village (Darmi, 2015). The government makes policy programs in rural areas in order to improve the welfare of the village community, for example the State of Jammu \& Kashmir (Sheikh, 2018). Moreover, most of the problems faced are caused by the Village Apparatus' low capacity as the manager of the Village Funds. It has the potential to result in Village Funds not being managed effectively and efficiently. To overcome this problem, it is necessary to develop the Village Apparatus's capacity so that the village community can maximally utilize the Village Funds. 
Several previous studies explained the importance of institutional capacity in running the organization's wheels (Brown, Lafond, \& Macintyre, 2001; M. Grindle, 2010; Habir \& Larasati, 1999; Horton, 2003; Matachi, 2006; Milen, 2001; Winterton, Warburton, Clune, \& Martin, 2014). In an institution, there is a dimension that plays the most role in managing the organization through institutional strengthening, including 3 (three) institutional elements, one of which is the development of the Village Apparatus's capacity. A notion stated by Grindle (M. S. Grindle, 2011; Milen, 2001) places human resource capacity development as a priority in the capacity building program, which needs to be considered by the local government. HR-State Civil Apparatus is very important for institutions/organizations because it supports the performance of the institution through work, talent, creativity, and a fundamental role in achieving the vision and mission of an institution/organization (Darmi, Suwitri, Yuwanto, \& Sundarso, 2017).

The existence of human resources (Village Apparatus) who have a qualified capacity can be the key to solving problems in improving organizational performance (Darmi et al., 2017; Sunarsi, 2019), Likewise, the management of village funds requires the capacity of village apparatus resources. In addition, the management of village funds requires community participation (Hulu, Harahap, \& Nasution, 2018). Accountability in managing village funds is in dire need of human resources who have the capacity (Saputra, Pradnyanitasari, Priliandani, \& Putra, 2019), planning in financial management is also important for increasing apparatus resources (Arma, Junaidi, \& Jaffisa, 2020). Efforts are being made to develop the capacity of the Village Apparatus (Manalu, Nasution, \& Nasution, 2019).

The capacity of the Village Apparatus in managing the Village Fund is a vital need since a village needs HR-Village Apparatus. They are qualified in financial management and wealth management. Without qualified HR-Village Apparatus, it can be ascertained that village governance and Village Fund management will experience difficulties. In increasing organizational management capacity, the most important dimension that needs to be built at an early stage is the capacity of the HR-Village Apparatus. This human resource capacity is expected to be a trigger to increase other fields' capacity, for example, the capacity in regional financial management. The study focused on 30 villages in the Bengkulu Province area located adjacent to the City area and aimed to find out how the capacity of village apparatus resources in managing village funds

\section{RESEARCH METHOD}

This study used qualitative and quantitative approaches, namely frequency percentage statistics. Data sources included primary and secondary data. There were 30 villages as the research objects, consisting of 10 villages in the North Bengkulu Regency, ten villages in the Seluma Regency, and ten villages in Central Bengkulu Regency. These villages were selected since they had maximum progress in the last four years or after village funds. This study prioritized village heads, village secretaries, or village apparatus as respondents because they had a role in managing village funds. There were two respondents taken from each village, so that the researchers obtained 60 respondents.

Data analysis was performed using frequency distribution statistics including 1) a Cumulative number of the highest score $=$ number of respondents $\times$ the highest measurement score; 2) a Cumulative number of the lowest score $=$ number of respondents $\times$ the lowest measurement score; 3) Highest percentage value; 4) The smallest percentage value; 5) Range value; 6) Interval value. The assessment criteria for each variable used are shown in Table 1.

Table 2. Assessment Criteria

\begin{tabular}{cc}
\hline Percentage interval & Assessment Criteria \\
\hline $20-35$ & Very Poor \\
\hline $31-51$ & Poor \\
\hline $52-67$ & Fair \\
\hline $68-83$ & Good \\
\hline $84-100$ & Very Good \\
\hline
\end{tabular}


The most prominent or dominant indicator of an increase of the capacity of the HR-Village Apparatus in managing village funds was determined by adding up all the answers to the questions assessed by the respondent from each indicator. The highest percentage of each indicator was determined as the most prominent or dominant indicator.

\section{RESULT AND DICUSSION}

\section{Existing Village Apparatus Education Level}

In Indonesia, education level becomes the standard or benchmark in accepting employees who will work in institutions (organizations). It indicates that an indicator of education is the main factor in accepting someone for a job. In the election of the village head, the education indicator becomes the benchmark. Based on Article 33 of the Village Law, one of the requirements to run for office as village head is to complete junior high school (SMP) or equivalent.

Based on Law on the National Education System Number 20 of 2003, formal education is held in schools through learning and teaching in stages and continuously. Adjustment of standards, requirements for village heads, and other village apparatus in occupying the village head (village apparatus) is the standard for the low education level. This is because the average Indonesian population only attends junior high school (an average of 8 years of education). The village apparatus's educational level in Bengkulu province has exceeded the standards, as shown in the following table.

Table 3. Education Level of Village Head in Bengkulu Province

\begin{tabular}{|c|c|c|c|c|c|c|c|c|}
\hline \multirow[b]{2}{*}{ No } & \multirow[b]{2}{*}{ Regencies } & \multirow{2}{*}{$\begin{array}{l}\text { Number of } \\
\text { Villages }\end{array}$} & \multicolumn{5}{|c|}{ Education Level } & \multirow[b]{2}{*}{ Note } \\
\hline & & & $\mathbf{S 2}$ & S1 & D1-D3 & SHS & $\begin{array}{l}\text { JHS/Elementa } \\
\text { ry School }\end{array}$ & \\
\hline 1 & $\begin{array}{l}\text { South Bengkulu } \\
\text { Regency }\end{array}$ & 142 & - & 41 & 8 & 91 & 2 & \\
\hline 2 & $\begin{array}{l}\text { North Bengkulu } \\
\text { Regency }\end{array}$ & 215 & - & 47 & 17 & 142 & 9 & \\
\hline 3 & Rejang Lebong Regency & 122 & - & 23 & 2 & 85 & 12 & \\
\hline 4 & Kaur Regency & 192 & - & 15 & - & 113 & 3 & $\begin{array}{l}\text { Sixty-one } \\
\text { people have } \\
\text { no data. }\end{array}$ \\
\hline 5 & Seluma Regency & 182 & - & 37 & 19 & 108 & 18 & \\
\hline 6 & Mukomuko Regency & 148 & 2 & 36 & 2 & 93 & 10 & \\
\hline 7 & Lebong Regency & 93 & - & 23 & 2 & 62 & 6 & \\
\hline 8 & Kepahyang Regency & 105 & - & 31 & 3 & 69 & 2 & \\
\hline 9 & $\begin{array}{l}\text { Central Bengkulu } \\
\text { Regency }\end{array}$ & 142 & - & 39 & 5 & 95 & 3 & \\
\hline
\end{tabular}

The table above shows that most village heads in Bengkulu province (858 village heads or 64\%) completed senior high school. Moreover, $21 \%$ of village heads graduated with a bachelor's degree (S1); $21 \%$ of village heads graduated with a Diploma (D1-D3); $5 \%$ of village heads graduated junior high school and elementary school, and $0.1 \%$ or two village heads graduated with Master's Degree (S2). This information confirms that the average population of Bengkulu Province attends school for 8-10 years.

In order to make sure that village apparatus has necessary Capability, management capability, and technical Capability in managing their villages, especially in managing village funds, the government has made various efforts such as providing technical guidance for village apparatus, comparative studies to independent villages on the island of Java, village financial system training, and Student Resource Development training.

\section{Characteristics of Research Respondents}

HR-Village Apparatus plays a significant role in managing village funds and supporting the performance of the village government. Implementation of the Village Budget program requires human resources to effectively and efficiently support the implementation of the program. Thus, the village 
government's goals can be achieved with the availability of adequate human resources with integrity. In the context of the village government's implementation, the village head and village secretary are human resources who are very instrumental in village funds management's success. The following are the characteristics of the respondents by sex.

Table 4. Characteristics of Respondents by Sex

\begin{tabular}{cllcc}
\hline No & Sex & & Total & Percentage \\
\hline 1 & Males & & 49 & $81.6 \%$ \\
2 & Females & \multirow{2}{*}{ Total } & 11 & $18.4 \%$ \\
& & 60 & $100 \%$ \\
\hline
\end{tabular}

Source: Research result, 2019

Based on the table above, $52 \%$ of HR-Village Apparatus who became respondents in this study were males, while $48 \%$ were females. In general, the research results explain that HR education contributes to individual and organizational performance. From the distribution of education, the respondents of this study are shown in the table below.

Table 5. Characteristics of Respondents by Education Level

\begin{tabular}{clcc}
\hline No & \multicolumn{1}{c}{ Education } & Total & Percentage \\
\hline 1 & Bachelor's Degree (S1) & 14 & $23.4 \%$ \\
\hline 2 & Diploma 2-Diploma 3 (D2-D3) & 4 & $6.6 \%$ \\
& & & $68.4 \%$ \\
\hline 3 & Senior High School (SHS) & 41 & $1.6 \%$ \\
\hline 4 & Junior High School (JHS) & 1 & $100 \%$ \\
\hline
\end{tabular}

Source: Research result, 2019

The table above demonstrates that 41 respondents (68.4\%) completed high school, while 14 respondents $(23.4 \%)$ graduated with a bachelor's degree (S1). Besides, four respondents $(6.6 \%)$ graduated with a Diploma (D2-D3), and one respondent (1.6\%) completed junior high school. More importantly, the primary indicator of the capacity of the HR-Village Apparatus in managing village funds is that at least the village apparatus has three abilities: essential Capability, management capability, and technical Capability. Questions asked for village apparatus were related to 1) Basic Capability had by village apparatus consists of knowledge about: 1.a) regulations related to village funds; 1.b) knowledge about primary duties and functions; 1.c) knowledge related to leadership and collaboration; 1.d) knowledge related to decision making and negotiation; 1.e) knowledge about conflict management. 2) Questions related to management Capability consist of 2.a) Capability to provide services to the community; 2.b) capability to empower and manage village assets; 2 .c) capability to manage village funds according to community needs; 2 .d) capability to manage village administration; 2.e) capability to explore village potential. 3) Questions related to the technical Capability of village apparatus including; 3 .a) Capability to make village regulations; $3 . b$ ) Capability to plan development with village funds; 3.c) Capability to make village funds management reports; 3.d) Capability to direct and lead; 3.e) Capability to organize village institutions.

Results of a field study on respondents' responses to the capacity of village apparatus in managing village funds seen from the essential Capability had included: 1.a) knowledge about regulations related to village funds; $1 . b)$ knowledge about primary duties and functions; 1 .c) knowledge related to leadership and collaboration; 1.d) knowledge related to decision making and negotiation; 1.e) knowledge about conflict management, shown as follows: 
Table 6. Essential Capability of Village Apparatus

\begin{tabular}{|c|c|c|c|c|c|c|c|c|c|c|c|c|}
\hline \multirow{3}{*}{$\begin{array}{l}\text { Statement } \\
\text { Numbers }\end{array}$} & \multicolumn{10}{|c|}{ Alternative Answers } & \multicolumn{2}{|c|}{ Total } \\
\hline & \multicolumn{2}{|c|}{ Very Good } & \multicolumn{2}{|c|}{ Good } & \multicolumn{2}{|c|}{ Fair } & \multicolumn{2}{|c|}{ Poor } & \multicolumn{2}{|c|}{ Very Poor } & & \\
\hline & $\mathrm{F}$ & $\%$ & $\mathrm{~F}$ & $\%$ & $\bar{F}$ & $\%$ & $\mathrm{~F}$ & $\%$ & $\mathrm{~F}$ & $\%$ & $\mathrm{~F}$ & $\%$ \\
\hline $1 \mathrm{a}$ & 5 & 8.3 & 25 & 41.7 & 20 & 33.3 & 10 & 16.7 & 0 & 0 & 60 & 100 \\
\hline $1 \mathrm{~b}$ & 4 & 6.7 & 26 & 43.3 & 25 & 41.7 & 5 & 8.3 & 0 & 0 & 60 & 100 \\
\hline $1 \mathrm{c}$ & 3 & 5 & 22 & 36.7 & 20 & 33.3 & 15 & 25 & 0 & 0 & 60 & 100 \\
\hline $1 \mathrm{~d}$ & 3 & 5 & 20 & 33.3 & 22 & 36.7 & 15 & 25 & 0 & 0 & 60 & 100 \\
\hline $1 \mathrm{e}$ & 2 & 3.3 & 19 & 31.7 & 24 & 40 & 15 & 25 & 0 & 0 & 60 & 100 \\
\hline Average & \multicolumn{2}{|c|}{$5.66 \%$} & \multicolumn{2}{|c|}{$37.34 \%$} & \multicolumn{2}{|c|}{$37 \%$} & \multicolumn{2}{|c|}{$20 \%$} & \multicolumn{2}{|c|}{ 0\% } & \multicolumn{2}{|c|}{$100 \%$} \\
\hline
\end{tabular}

Source: Research result, data processed, 2019.

The table above shows primary data in the field. It demonstrates that for question number 1a regarding the knowledge of village apparatus about regulations related to village funds, $41.7 \%$ of respondents chose 'good'; $33.3 \%$ of respondents chose 'fair'; about $16.7 \%$ of respondents chose 'poor' in understanding village funds management, and about $8.3 \%$ of respondents chose 'very good.' For question $1 \mathrm{~b}$ regarding knowledge about primary duties and functions, $43.3 \%$ of respondents chose 'good'; $41.7 \%$ of respondents chose 'fair'; $8.3 \%$ of respondents chose 'poor,' and about $6.7 \%$ of respondents chose 'very good.' Furthermore, for question 1c regarding knowledge related to leadership and collaboration, $36.7 \%$ of respondents chose 'good'; $33.3 \%$ of respondents chose 'fair'; $25 \%$ of respondents chose 'poor,' and the remaining $6.7 \%$ chose 'very good.' For question $1 \mathrm{~d}$ regarding knowledge related to decision making and negotiation, $36.7 \%$ of respondents chose 'fair'; $33.3 \%$ chose 'good'; $25 \%$ chose 'poor,' and 5\% chose 'very good.' For the last one, question 1e regarding knowledge about conflict management, $40 \%$ of respondents chose 'fair'; $37.34 \%$ chose 'good'; $25 \%$ of respondents chose 'poor,' and 3.3\% of respondents chose 'very good.'

The results showed that the village apparatus needed to have the necessary Capability in managing village funds. It was confirmed by $37.34 \%$ of respondents stating 'good,' that the capacity of village apparatus in managing village funds had necessary Capability. It means that the village apparatus should be able to increase their capacity to carry out their duties professionally. The necessary Capability had by the village apparatus can support the village funds management effectively and efficiently.

\section{Management Capability of Village Apparatus}

Results of a field study on respondents' responses to the capacity of village apparatus in managing village funds seen from the management capability had included questions regarding 2.a) Capability to provide services to the community; 2.b) capability to empower and manage village assets; 2.c) capability to manage village funds according to community needs; 2 .d) capability to manage village administration; 2.e) capability to explore village potential. The results of respondent's response regarding those items are shown in the table below.

Table 7. Management Capability of Village Apparatus

\begin{tabular}{|c|c|c|c|c|c|c|c|c|c|c|c|c|}
\hline \multirow{3}{*}{$\begin{array}{l}\text { Statement } \\
\text { Numbers }\end{array}$} & \multicolumn{10}{|c|}{ Alternative Answers } & \multirow{2}{*}{\multicolumn{2}{|c|}{ Total }} \\
\hline & \multicolumn{2}{|c|}{ Very Good } & \multicolumn{2}{|c|}{ Good } & \multicolumn{2}{|c|}{ Fair } & \multicolumn{2}{|c|}{ Poor } & \multicolumn{2}{|c|}{ Very Poor } & & \\
\hline & $\mathbf{F}$ & $\%$ & $\mathbf{F}$ & $\%$ & $\mathbf{F}$ & $\%$ & $\mathbf{F}$ & $\%$ & $\mathbf{F}$ & $\%$ & $\mathbf{F}$ & $\%$ \\
\hline $2 a$ & 5 & 8.3 & 30 & 50 & 20 & 33.3 & 5 & 8.3 & 0 & 0 & 60 & 100 \\
\hline $2 \mathrm{~b}$ & 4 & 6.6 & 25 & 41.7 & 15 & 25 & 14 & 23.3 & 2 & 3.3 & 60 & 100 \\
\hline $2 c$ & 2 & 3.3 & 16 & 26.7 & 20 & 33.3 & 20 & 33.3 & 2 & 3.3 & 60 & 100 \\
\hline $2 \mathrm{~d}$ & 1 & 1.6 & 23 & 38.3 & 19 & 31.6 & 17 & 28.3 & 0 & 0 & 60 & 100 \\
\hline $2 \mathrm{e}$ & 2 & 3.3 & 14 & 23.3 & 25 & 41.6 & 14 & 23.3 & 5 & 8.3 & 60 & 100 \\
\hline Average & & $6 \%$ & & $6 \%$ & & & & & & & & \\
\hline
\end{tabular}


Source: Research result, data processed, 2019.

The table above shows primary data in the field. It demonstrates that for question 2a regarding Capability to provide services to the community, $50 \%$ of respondents chose 'good'; $33.3 \%$ of respondents chose 'fair'; $8.3 \%$ of respondents chose 'very good' in providing services to the community, and $8.3 \%$ of respondents chose 'poor.' For question $2 \mathrm{~b}$ regarding Capability to empower and manage village assets, $41.7 \%$ of respondents chose 'good'; $25 \%$ of respondents chose 'fair'; $23.3 \%$ of respondents chose 'poor'; about $6.6 \%$ of respondents chose 'very good'; and 3,3\% of respondents chose 'very poor.'

Moreover, for question $2 \mathrm{c}$ regarding capability to manage village funds according to community needs, $33.3 \%$ of respondents chose 'fair'; $33.3 \%$ of respondents chose 'poor'; $26.7 \%$ of respondents chose 'good'; and 3.3\% of respondents chose 'very good'; and 3.3\% of respondents chose 'very poor.' For question $2 \mathrm{~d}$ regarding capability to manage village administration, $38.3 \%$ of respondents chose 'good'; $31.6 \%$ of respondents chose 'fair'; and $28.3 \%$ of respondents chose 'poor'; $1.6 \%$ of respondents chose 'very good.'

Additionally, for question $2 \mathrm{e}$ regarding capability to explore village potential, $41.6 \%$ of respondents chose 'fair'; $23.3 \%$ of respondents chose 'good'; $23.3 \%$ of respondents chose 'poor,' dan $8.8 \%$ of respondents chose 'very poor'; and $3.3 \%$ of respondents chose 'very good.'

Based on data in the field, for management capability, $36.6 \%$ of respondents chose 'good'; $33 \%$ of respondents chose 'fair'; $23.3 \%$ of respondents chose 'poor'; $4.6 \%$ of respondents chose 'very good'; and $2.98 \%$ of respondents chose 'very poor.'

The results showed that based on management capability, the village apparatus's capacity received a 'good' response, but $26.28 \%$ of respondents chose 'poor' (when combined with 'abysmal' percentage). It means that the management capability of the village apparatus needs to be improved. Besides, the village apparatus should increase its capacity so that village funds management can be carried out effectively and efficiently.

\section{Technical Capability of Village Apparatus}

Results of a field study on respondents' responses to village apparatus capacity in carrying out duties seen from technical Capability. 3) Questions related to the technical Capability of village apparatus included: 3.a) capability to make village regulations; 3.b) Capability to plan development with village funds; 3.c) capability to make village funds management reports; 3.d) Capability to direct and lead; 3.e) Capability to organize village institutions. The results of the respondent's response regarding those items are shown in table 8.

Table 8. Technical Capability of Village Apparatus

\begin{tabular}{|c|c|c|c|c|c|c|c|c|c|c|c|c|}
\hline \multirow{3}{*}{$\begin{array}{c}\text { Statement } \\
\text { Numbers }\end{array}$} & \multicolumn{10}{|c|}{ Alternative Answers } & \multirow{2}{*}{\multicolumn{2}{|c|}{ Total }} \\
\hline & \multicolumn{2}{|c|}{$\begin{array}{l}\text { Very } \\
\text { Good }\end{array}$} & \multicolumn{2}{|c|}{ Good } & \multicolumn{2}{|c|}{ Fair } & \multicolumn{2}{|c|}{ Poor } & \multicolumn{2}{|c|}{ Very Poor } & & \\
\hline & $\mathbf{F}$ & $\%$ & $\mathbf{F}$ & $\%$ & $\mathbf{F}$ & $\%$ & $\mathbf{F}$ & $\%$ & $\mathbf{F}$ & $\%$ & $\mathbf{F}$ & $\%$ \\
\hline $3 a$ & 6 & 10 & 13 & 21.7 & 26 & 43.3 & 11 & 18.3 & 4 & 6.6 & 60 & 100 \\
\hline $3 \mathrm{~b}$ & 4 & 6.7 & 19 & 31.7 & 19 & 31.7 & 14 & 23.3 & 4 & 6.6 & 60 & 100 \\
\hline $3 c$ & 4 & 6.7 & 26 & 43.3 & 23 & 38.3 & 6 & 10.3 & 1 & 1.7 & 60 & 100 \\
\hline $3 d$ & 4 & 6.6 & 23 & 38.3 & 24 & 40 & 9 & 15 & 0 & 0 & 60 & 100 \\
\hline $3 \mathrm{e}$ & 4 & 6.6 & 22 & 36.7 & 24 & 40 & 10 & 16.7 & 0 & 0 & 60 & 100 \\
\hline Average & & $2 \%$ & & $4 \%$ & & $6 \%$ & & \%\% & & $\%$ & & \\
\hline
\end{tabular}

Source: Research result, data processed, 2017.

Table above shows primary data in the field. It demonstrates that for question 3a regarding capability to make village regulations, $43.3 \%$ of respondents chose 'fair'; $31.7 \%$ of respondents chose 
'good'; $23.3 \%$ of respondents chose 'poor'; $10 \%$ of respondents chose 'very good'; and $6.6 \%$ of respondents chose 'very poor.'

For question $3 \mathrm{~b}$ regarding capability to plan development with village funds, $31.7 \%$ of respondents chose 'good'; $31.7 \%$ of respondents chose 'fair'; $23.3 \%$ of respondents chose 'poor'; about $6.7 \%$ of respondents chose 'very good'; $6.6 \%$ of respondents chose 'very poor.' For question 3c regarding capability to make village funds management reports, $43.3 \%$ of respondents chose 'good'; $31.7 \%$ of respondents chose 'fair'; $23.3 \%$ of respondents chose 'poor'; $6.7 \%$ of respondents chose 'very good'; and $1.7 \%$ of respondents chose 'very poor.'

More importantly, for question $3 \mathrm{~d}$ regarding capability to direct, lead, and evaluate village funds, $40 \%$ of respondents chose 'fair'; 38.3\% of respondents chose 'good'; $15 \%$ of respondents chose 'poor'; and $6.6 \%$ of respondents chose 'very good.' For the last question, 3e, regarding capability to organize village institutions, $40 \%$ of respondents chose 'fair'; $36.7 \%$ of respondents chose 'good'; $16.7 \%$ of respondents chose 'poor'; and $8.8 \%$ of respondents chose 'very good.'

Table 8 above also shows that for the village apparatus's capacity, in terms of technical Capability, $38.66 \%$ of respondents chose 'fair.' In comparison, $34.34 \%$ of respondents chose 'good.' Empirical data show that no respondent has given a "good" response above the $50 \%$ percentile for the three abilities that village apparatus should have in managing village funds. It means that the village apparatus needs to increase individual capacity, both formally and informally, so that the village funds management can be carried out effectively and efficiently.

To find out the capacity of the village apparatus in managing village funds, a comparison was made between the total score of the answers to the 15 items, which was 2,911, with the highest total score of $5 \times 60 \times 15=4,500$, so the result of the comparison was $2,911: 4,500=0.646$ or $0.646 \times 100 \%$ $=64.6 \%$. Adjusted to the assessment criteria, the value of $64.6 \%$ is in the range of percentage intervals between 52 - 67. It shows that the village apparatus's Capability in managing village funds is in the "fair" category. A prominent or dominant indicator of the village apparatus's capacity to manage village funds can be seen from variables of village apparatus capabilities determined by adding up each indicator's total score. This is shown in the table below.

Table 9. Distribution of Percentage of Village Head Professionalism by Research Indicators

\begin{tabular}{llcc}
\hline No. & Research Indicators & $\sum$ & $\mathbf{\%}$ \\
\hline 1. & Necessary Capability of Village Apparatus & 986 & 33.88 \\
\hline 2. & Management Capability of Village Apparatus & 946 & 32.49 \\
\hline 3. & Technical Capability of Village Apparatus & 979 & 33.63 \\
\hline \multicolumn{2}{c}{ TOTAL } & $\mathbf{2 . 9 1 1}$ & $\mathbf{1 0 0}$ \\
\hline
\end{tabular}

Source: processed by the researchers, 2019.

The table above explains that the most prominent or dominant indicator in village apparatus capacity is necessary Capability with a contribution of 33.88\%. Respondents' assessment of the most dominant indicator owned by village apparatus in managing village funds is necessary Capability which is seen from knowledge about regulations related to village funds, primary duties, and functions, knowledge related to leadership and collaboration, knowledge related to decision making and negotiation, and knowledge about conflict management. It means that by having the necessary capabilities in managing village funds, the village apparatus has knowledge of the basics of village governance, regulations, or policies regarding villages and has the Capability to translate and apply their primary duties and authorities.

The management capability indicator reflected in the village apparatus's ability to manage village funds has shown a 'good' category by allocating village funds for human resource development. This implies that the village apparatus can coordinate and direct related parties in formulating and making policy decisions. Village apparatus can empower the community, for example, training for housewives to improve skills; recitation every Friday afternoon. They also provide tips on increasing the individual capacity of mothers to improve the social class.

Furthermore, the technical Capability indicator, seen from the village apparatus's ability in planning village development, confirms that the village apparatus has involved the community and 202 | Titi Darmi', lqbal Miftakhul Mujtahid ${ }^{2}$ 
accommodated community suggestions in deciding policies. The community believes that the village apparatus can make a Village Budget as a village guide in implementing development programs. The village apparatus can make village regulations in the interests of the community. They are also considered having the Capability to prepare village administration. However, they have not received responses from respondents above $50 \%$ on each indicator of Capability owned by the village apparatus. Based on empirical data in the field, in general, the Capability of village apparatus in managing village funds is assessed from their necessary Capability, management capability, and technical Capability, all of which are in the 'fair' category. It means that the village apparatus needs to increase its capacity so that village funds can be managed optimally.

The findings in this study explain that education has implications for the performance of the village government. It supports a previous study conducted by (Rasheed Memon, 2014) that from the dimensions of Capability in government management in the form of expertise, learning, policies and procedures, data and documents, knowledge has a causal relationship with actions that have been identified in organizational performance (Sunahwati, Maarif, \& Sukmawati, 2019). The study results also support the findings of this study which states that human resource capacity development through education, training, and workshops can help HR have the responsibility to ensure the survival and success of organizational Management (Oyedele, 2016).

Matters that become strategic issues in increasing village apparatus capacity serve as guidelines for implementing future policies. The first issue is that the village government apparatus's average education level in Bengkulu province is at the senior high school level and equivalent. Senior high school education is in the inadequate category, meaning that the low level of village apparatus education is one of the elements that can contribute to the performance of implementing village funds management. The second issue is that the experience of village apparatus in managing finances is still minimal; for example, limited experience in managing finances right on target can cause problems in managing village funds. One of the impacts is that the implementation of village funds is not by the community's needs. The third issue is that there is no stakeholder commitment and consistency in increasing village apparatus capacity in a systematic, programmed, and sustainable manner.

Village Fund is a budget sourced from the State Budget (APBN) allocated to villages transferred through the Regional Budget (APBD), which is intended for financing to organize village governance, carry out development, empower communities, and welfare village communities. The State Budget for village funds always increases every year. The management of village funds requires a village apparatus with qualified capabilities so that village funds can be managed optimally.

\section{CONCLUSION}

Based on empirical data in the field, the village apparatus's capacity in managing village funds is generally assessed from their necessary Capability, management capability, and technical Capability, which fall into the 'fair' category. It indicates that the village apparatus needs to increase its capacity so that village funds can be managed optimally. Empirical data show that a prominent or dominant indicator of the village apparatus's capacity in managing village funds can be seen from variables of village apparatus capabilities that are determined by adding up the total score of each indicator. By comparing the total score of the answers to the 15 items, which was 2,911, with the highest total score of $5 \times 60 \times 15=4,500$, the result of the comparison was 2,911: $4,500=0.646$ or $0.646 \times 100 \%=64.6 \%$. Adjusted to the assessment criteria, the value of $64.6 \%$ is in the range of percentage intervals between 52 - 67. It shows that the village apparatus's Capability in managing village funds is in the "fair" category.

The researchers offer the following solutions: 1) village apparatus should get training and technical guidance related to planning, implementing, evaluating, and making village development program reports (in which there is a village funds program); 2) there is a need for a training assistance program for the development of human resources (village apparatus) on a sustainable basis; 3) Relevant agencies collaborate with local universities to increase the level of 
education and learning experience of village apparatus. If these three solutions are implemented consistently, the village apparatus will have a qualified capacity to manage village funds. They will automatically have the three capabilities that every village apparatus must-have. This study recommends the need to strengthen the capacity of village apparatus resources in managing village funds by fulfilling the essential capabilities, management capability, and technical capability.

\section{ACKNOWLEDGEMENT}

The researchers would like to express their deepest gratitude to Universitas Terbuka for providing support in completing this study.

\section{REFERENCE}

Arma, N. A., Junaidi, \& Jaffisa, T. (2020). Peningkatan Aparatur Dalam Perencanaan Pembangunan Desa di Desa Kota Rantang. RESWARA: Jurnal Pengabdian Kepada Masyarakat, 1(2). https://doi.org/10.46576/rjpkm.v1i2.573

Brown, L., Lafond, A., \& Macintyre, K. (2001). Measuring Capacity Building. (March), 919-966. Retrieved from www.cpc.unc.edu/measure

Darmi, T. (2015). Indonesia Dalam Menghadapi MEA Dalam Perspektif Meningkatkan Kapasitas Aparatur Desa. In Sunarto, A. Marom, Fitriani, S. Suwitr, \& Kismartini (Eds.), Peluang dan Tantangan Indonesia Menyongsong Asean Economic Community ( Masyarakat Ekonomi Asean ) melalui Inovasi Kebijakan dan Manajemen Publik (p. 169). Semarang Kota: Program Studi Doktor Administrasi Publik FISIP Universitas Diponegoro.

Darmi, T., \& Mujtahid, I. M. (2019). Peningkatan Kapasitas Kebijakan Dana Desa Dalam Mengentaskan Kemiskinan. Journal of Indonesian Public Administration and Governance Studies (JIPAGS), 3(2), 671-683. Retrieved from http://jurnal.untirta.ac.id/index.php/JIPAGS/article/view/5484

Darmi, T., Suwitri, S., Yuwanto, \& Sundarso. (2017). Capacity Building as Accelerator for Improving Autonomous Region Recently Knows as (DOB): Case Study in Seluma Distrcit Bengkulu Province, Indonesia. Journal of Public Administration and Governance, 7(3). https://doi.org/10.5296/jpag.v7i3.11657

Grindle, M. (2010). Good Governance: The Inflation of an Idea. Harvard University, Center for International Development, (June), 1-21.

Grindle, M. S. (2011). Good Enough Governance Revisited. Development Policy Review, 29(SUPPL. 1), 553-574. https://doi.org/10.1111/j.1467-7679.2011.00526.x

Habir, A. D., \& Larasati, A. B. (1999). Human resource management as competitive advantage in the new millennium - An Indonesian perspective. International Journal of Manpower, 20(8), 548-562. https://doi.org/10.1108/01437729910302732

Horton, D. (2003). Evaluating Capacity Development: Experiences from Research and Development Organizations around the World. Retrieved from https://www.idrc.ca/en/book/evaluating-capacity-development-experiences-researchand-development-organizations-around-world

Hulu, Y., Harahap, R. H., \& Nasution, M. A. (2018). Jurnal Pendidikan Ilmu-Ilmu Sosial Pengelolaan Dana Desa dalam Pemberdayaan Masyarakat. Jurnal Pendidikan Dam Ilmu-Ilmu Sosial, 10(1), 146-154.

KemenKeu. (2016). Alokasi Dana Desa Tahun 2016 Menurut Kabupaten/Desa (pp. 1-7). pp. 1-7. Jakarta: www.djpk.kemenkeu.go.id/web/attachments/.../DANADESA2016.pdf. 
Manalu, M., Nasution, H. T., \& Nasution, I. (2019). Pengembangan Kapasitas Aparatur Pemerintah Desa di Desa Aek Korsik. Perspektif, 7(2), 55-59.

Matachi, A. (2006). Capacity Building Framework. UNESCO - International Institute for Capacity Building in Africa, 1-28.

Milen, A. (2001). What do we know about capacity building? An overview of existing knowledge and good practice (Vol. 0). https://doi.org/10.3109/10641969009073509

Mujtahid, I. M., \& Darmi, T. (2019). Reinforcement the capacity of village fund management to improve the economy of local communities (Indonesia example). International Journal of Scientific and Technology Research, 8(10), 3659-3668.

Oyedele, S. O. (2016). Employee Compensation Management: The Case of The National Minimum Wage in Nigeria. Journal of Human Resource Management, XIX(1), 51-55.

Rasheed Memon, K. (2014). Strategic Role of HRD in Employee Skill Development: An Employer Perspective. Journal of Human Resource Management, 2(1), 27. https://doi.org/10.11648/j.jhrm.20140201.15

RI, D. P. dan P. K. (2015). Laporan Kajian"Pengelolaan Keuangan Desa: Alokasi Dana Desa dan Dana Desa. Jakarta: acch.kpk.go.id/...Laporan+Kajian...Desa.../292dcf24-b997-44a6-b51e.

Saputra, K. A. K., Pradnyanitasari, P. D., Priliandani, N. M. I., \& Putra, I. G. B. N. P. (2019). Praktek Akuntabilitas Dan Kompetensi Sumber Daya Manusia Untuk Pencegahan Fraud Dalam Pengelolaan Dana Desa. Jurnal KRISNA: Kumpulan Riset Akuntansi, 10(2), 168-176.

Sheikh, Y. A. (2018). Implementation of rural development programmes in jammu and kashmir. Journal of Governance And Public Policy, 5(1), 45-58. https://doi.org/: https://doi.org/10.18196/jgpp.5191

Sunahwati, E., Maarif, M. S., \& Sukmawati, A. (2019). Human Resources Development Policy as a Strategy for Improving Public Organizational Performance. JKAP (Jurnal Kebijakan Dan Administrasi Publik), 23(1), 50. https://doi.org/10.22146/jkap.37957

Sunarsi, D. (2019). Penerapan MSDM Strategis Dalam Upaya Meningkatkan Kemampuan Organisasi dalam. Jurnal Ilmiah MEA (Manajemen, Ekonomi, \& Akuntansi), 3(1), 221-233. https://doi.org/10.31955/mea.vol3.iss1.pp221-233

Winterton, R., Warburton, J., Clune, S., \& Martin, J. (2014). Building Community and Organisational Capacity to Enable Social Participation for Ageing Australian Rural Populations: A ResourceBased Perspective. Ageing International, 39(2), 163-179. https://doi.org/10.1007/s12126013-9187-2 